\title{
Koda: Lektura dyskursu świadka
}

Hayden White

TEKSTY DRUGIE 2018, NR 3, S. 196-201

DOI: $10.18318 / \mathrm{td} .2018 .3 .13$

$\mathbf{0}$ twieram drugi tom głośnej książki Saula Friedländera Czas eksterminacji. Nazistowskie Niemcy i Żydzi 1939-1945 (2008) [2010], spodziewając się deklaracji początkowej w rodzaju tej, która otwiera podobnie głośne studium Richarda J. Evansa Trzecia Rzesza u władzy, 1933-1939 (2006) [2017]. Praca Evansa zaczyna się tak: „Niniejsza książka opowiada o dziejach Trzeciej Rzeszy [...] począwszy od momentu, w którym latem 1933 r. zakończyło się przejmowanie [...] władzy do [...] do początku września 1939" (s. 23). W książce Friedländera nie ma takiego rozpoczęcia; nie znajduję tam nawet stwierdzenia, że to „historia” nazistowskich Niemiec i Żydów. Zamiast tego - zaraz po tytule i dedykacji - na osobnej stronicy widnieją słowa w następującym układzie:

Wyraźnie czuję, jak tracę siły, jak jest mi coraz duszniej... Walka o osobisty ratunek staje się beznadziejna... [...] Ale to nieważne. Bo sprawozdanie moje mogę doprowadzić do końca i ufam, że ujrzy ono światło dzienne we właściwym czasie... I ludzie
Hayden White (1928-2018) - amerykański badacz teorii i historii historiografii, krytyk kultury, był profesorem historii świadomości na University of California w Santa Cruz oraz literatury porównawczej na Stanford University. Autor książek: Metahistory. The Historical Imagination in Nineteenth-Century Europe (1973), Figural Realism. Studies in the Mimesis Effect (1999), The Practical Past (2014). 
będą wiedzieć, jak to było. I zapytają, czy to prawda. I z góry odpowiem: nie, to nie jest prawda, to jest tylko niewielka cząstka, drobny ułamek prawdy. Ta istotna, cała, prawdziwa Prawda nie da się przedstawić najtęższym choćby piórem.

Stefan Ernest O wojnie wielkich Niemiec z Żydami Warszawy, 1939-1943

Pisane w 1943 r., w ukryciu po „aryjskiej” stronie Warszawy

Wciąż nie wiem, nie zostałem poinformowany, czy to „historia”, a jeśli tak, to czy uformowano ją w opowieść czy też jakiś inny rodzaj narracji. Na następnej stronie widzę nagłówek Spis treści, na kolejnej Podziękowania. Dopiero potem napotykam stronicę zatytułowaną Wstęp, ale zaczyna się ona następującym stwierdzeniem:

Osiemnastego września 1942 r. David Moffie otrzymał dyplom ukończenia studiów medycznych na Uniwersytecie Amsterdamskim. Na fotografii wykonanej podczas tej uroczystości po prawej ręce świeżo upieczonego lekarza stoją profesor CU Ariëns Kappers - promotor Moffiego, oraz profesor H.T. Deelman; po lewej stronie widzimy asystenta D. Granaata. (s. 13)

Dalej następuje dość wyczerpujący opis fotografii i objaśnienie „historycznej” doniosłości tego, co dokumentuje, a mianowicie „aktu oporu” ze strony władz uniwersyteckich, które nadały stopień naukowy Żydowi w przeddzień wejścia w życie zakazu Żydom studiów uniwersyteckich w Holandii, wprowadzonego przez niemieckich okupantów. W dodatku do tej informacji autor objaśnia nam jeszcze jeden wymiar zdjęcia. Dostrzega na smokingu Davida Moffiego gwiazdę Dawida z wyhaftowanym na niej słowem „Jood”, jaką wszyscy Żydzi znajdujący się pod niemiecką jurysdykcją zobowiązani byli nosić. Friedländer zwraca uwagę, że gwiazda ta nie tylko pozwala zidentyfikować jej nosiciela jako Żyda, ale że nosiciel został nią oznaczony po to, aby stać się ofiarą mordu. W rzeczy samej gwiazda jest zinterpretowana jako „zapowiedź" programu eksterminacji wszystkiego, co żydowskie, który był jednym z najważniejszych, jeśli nie wręcz najważniejszym aspektem nazistowskiego „ostatecznego rozwiązania kwestii żydowskiej” (s. 27).

W ten sposób zatem, poprzez objaśnienie pozornie mało znaczącego wydarzenia na peryferiach Trzeciej Rzeszy, które przypadkowo zostało sfotografowane, autor utrzymuje, że wyłożył czytelnikom „kwintesencję” „sytuacji”, 
jaką określił słowem „eksterminacja”. Dopiero po omówieniu wstępnej anegdoty Friedländer przechodzi do istoty tekstu znajdującego się w rękach czytelnika:

Historii Holokaustu nie należy sprowadzać jedynie do suchego opisu niemieckiej polityki, działań, decyzji i kroków, które doprowadziły do największego w dziejach zorganizowanego ludobójstwa. Należy uwzględnić również reakcje (a w określonych przypadkach również inicjatywy) otaczającego świata, a także postawy ofiar. Wydarzenia zwykle określane mianem „Holokaust” stanowią bowiem całość, na którą składa się zbiór nakładających się na siebie odrębnych elementów. [...] Historia Holokaustu winna być więc zarazem historią integrującą i zintegrowaną. (s. 15-16) [Ostatniego zdania brak w polskim przekładzie - M.W.]

W tym miejscu w tekście pojawia się przerwa, po której znajdujemy zdanie: „Nie istnieje jedna rama koncepcyjna, która pozwoliłaby objąć odmienne, splatające się ze sobą wątki tej historii" (s. 16).

Uważnie przeczytałem pierwsze strony znakomitej książki Friedländera, chwalonej za doskonały warsztat, wykorzystanie literatury przedmiotu oraz wartości literackie, aby uchwycić te spośród jej cech, które mają charakter raczej zasadniczo literacki aniżeli historiograficzny. Zrobiłem to także, ponieważ w niniejszym szkicu chcę się zająć różnicami między rozmaitymi świadectwami (dyskursem świadka). Friedländer sam uratował się z programu eksterminacji, o którym pisze. Czy więc jego „historia Holokaustu” daje się określić jako rodzaj pisarstwa „świadka”? Czy pisarstwo świadka ujawnia cechy czy właściwości, których brak innym rodzajom pisarstwa? Ci, którzy przeżyli Holokaust, zazwyczaj „dają mu świadectwo”, opowiadając o swoich przeżyciach. Co więcej, czynią to w różnych okolicznościach i kontekstach: religijnym, dziennikarskim, archiwistycznym, prawnym, literackim, politycznym itd. Owe okoliczności i konteksty nakładają ograniczenia na to, co może być powiedziane, a co nie, lub też czego nie wolno powiedzieć. Determinują także rozróżnienie między tym, co uważa się za historyczne świadectwo wydarzenia, a tym co jest jego świadectwem w obszarze fikcji literackiej.

Lektury pisanych bądź zapisanych relacji świadków Holokaustu można nauczyć się, czytając świadectwa literackie. Wskazówka ta zakłada jakościowe różnice między świadectwami ocalałych, ofiar, obserwatorów, katów itd. Nie mam tu na myśli różnic w rodzaju tych między świadectwami ustnymi 
i pisanymi, zeznaniami wobec prawa, wyznaniami, refleksjami autobiograficznymi, prozą opartą na doświadczeniach itd. Odnoszę się z jednej strony do świadectw przekazanych w wywiadach lub oświadczeniach związanych z przeżyciami osobistymi, z drugiej natomiast do utworów artystycznych. Różnicę tę można porównać do tych, jakie istnieją między kanonem a zespołem apokryfów uznawanych za święte lub przynajmniej godne pieczołowitego przechowywania i traktowania z szacunkiem przez zainteresowane społeczności czytelników. Dzieła kanoniczne nie tylko zawierają ważne informacje o wydarzeniach i postaciach, które uważa się za kluczowe dla tożsamości danej społeczności, lecz także dostarczają wzorców, wedle jakich określa się poprawność ich przedstawiania. Dzieła kanoniczne lub za takie uważane wyraźnie wysuwają na plan pierwszy funkcję poetycką i metajęzykową kosztem afektywnej i ekspresywnej funkcji wypowiedzi. Oznacza to, że wyrażają one dające się zidentyfikować „nastawienie” (Einstellung lub mentalną orientację) wobec tekstowego przekazu i koncentrują się na zasadzie ekwiwalencji, aby przetworzyć serie wydarzeń w ich sekwencje. Funkcja poetycka rozdziela znaczenie między powierzchnię i głębię tekstu, natomiast funkcja metajęzykowa dzieli je na osi horyzontalnej między początkiem a końcem.

W dyskursie prozatorskim zasadą jest, że przedmowa dostarcza wskazówek co do lektury tekstu. Dlatego wybitny specjalista w dziedzinie historii Niemiec rozpoczyna swą trzytomową pracę na temat Trzeciej Rzeszy od pouczenia, by czytać tomy po kolei od początku do końca dla zrozumienia całości wywodu. Istnieją oczywiście różnice między „surowymi” ustnymi relacjami świadków a bardziej świadomie sporządzonymi utworami pisarzy lub artystów w dziedzinach innych niż literatura. Być może jednak naprawdę ważne jest to, że z wyjątkiem przypadków składania zeznań w sądzie świadek jest mniej zainteresowany uzupełnieniem istniejących danych czy też dostarczeniem nowych informacji o Holokauście niż wyrażeniem cierpień spowodowanych swoimi przeżyciami. Ujmując rzecz w kategoriach dyskursywnych, świadek w sensie osoby dotkniętej doświadczeniem funkcjonuje przede wszystkim na ekspresywnym poziome swojej wypowiedzi, natomiast świadek w sądzie na poziomie referencji. Natomiast pisarz uruchamia również inne poziomy, zwłaszcza poetycki, gdzie pod względem sposobu przedstawienia, rozłożenia akcentów i organizacji wewnętrznej przekaz modelowany jest przez dyskurs, oraz metajęzykowy, który ujawnia różne kody służące semantyzacji. Nawet kiedy z początku daje osobiste świadectwo, pisarz taki jak Primo Levi jest szczególnie zainteresowany wypowiadaniem się zamiast lub w imieniu współwięźniów z Auschwitz po to, aby przekazać jak było, lecz 
także ukształtowaniem swego świadectwa życia i śmierci w obozie tak, aby wywołać u wyobrażonych odbiorców określone afekty i emocje.

Na poziomie referencji, kiedy celem jest ujawnienie prawdy w odniesieniu do faktów, Levi jest tak skrupulatny, jak to tylko możliwe, jednak wydaje się, że jego celem podstawowym pozostaje ewokacja życia codziennego w obozie po to, by czytelnicy mogli poczuć ciężar winy i odpowiedzialności, zarówno jeśli chodzi o udrękę więźniów, jak i o podejmowane przez nich wysiłki, by przeżyć.

Trzeba pamiętać, że jeśli chodzi o tak ważne wydarzenia historyczne jak Holokaust nie istnieje żadna „źródłowa” struktura zdarzeń, do której dane świadectwo może być przyrównane lub względem której może zostać uznane za wkład znaczący. Friedländer znany jest z tego, że opowiedział się za stworzeniem „ustalonej narracji normatywnej”, do której każdy pełny lub cząstkowy opis Holokaustu (Shoah lub „Ostatecznego Rozwiązania”) mógłby zostać porównany pod względem odpowiedniości i zgodności zjego przyjętą „istotą". Program eksterminacji europejskich Żydów przeprowadzony przez hitlerowskie Niemcy jest niezaprzeczalnym faktem (dla wszystkich z wyjątkiem tych, którzy twierdzą, że się nie wydarzył), lecz kwestia jego dokładnego określenia, wraz z przebiegiem i rezultatami, była równie niejasna jak kryteria potrzebne do wyznaczenia jego statusu w historii (kiedy się zaczął, jak postępował, jakie miał konsekwencje, a także, co istotne, na czym polega jego spuścizna). 


\section{Abstract}

\section{Hayden White}

UNIVERSITY OF CALIFORNIA (SANTA CRUZ)

STANFORD UNIVERSITY

Coda: Reading Witness Discourse

White analyses the difference between two types of historiographic discourse related to the Holocaust as represented in two outstanding studies on the subject. He argues that in the case of discourses connected to the witness's experience, it is not only the reference that plays a role but also the specific point of view and emotions of the rescued person. These are taken into account by Saul Friedländer.

\section{Keywords}

historiography, Holocaust, witness, experience, literary prose

\section{Bibliografia:}

Evans, R., The Third Reich in Power, 1933-1939; How the Nazis Won Over the Hearts and Minds of the Nation. Penguin: Nowy Jork, 2006. [Wyd. pol.: Trzecia Rzesza u Władzy, 1933-1939, przeł. M. Grzywa. Napoleon V: Oświęcim, 2017].

Friedländer, S., Nazi Germany and the Jews, 1939-1945: The Years of Extermination. Harper Collins: Nowy Jork, 2008. [Wyd. pol.: Czas eksterminacji. Nazistowskie Niemcy i Żydzi, 1939-1945, przeł. S. Kupisz, A.M. Nowak, K. Masłowski. Prószyński: Warszawa, 2010]. 